Working Paper No. 7, 2018

\title{
Mestizaje and Conviviality \\ in Brazil, Colombia and Mexico
}

Peter Wade
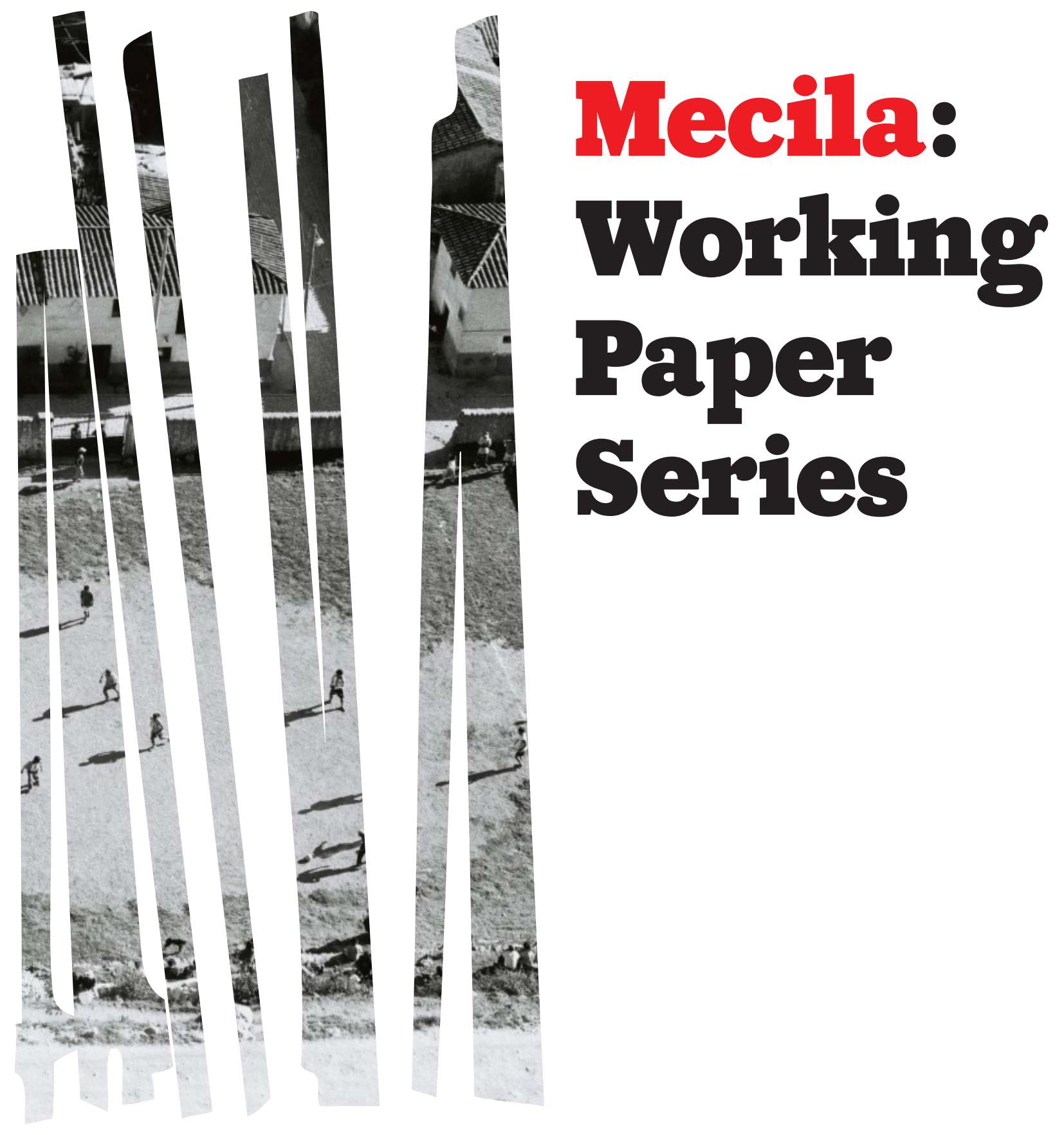

Paper

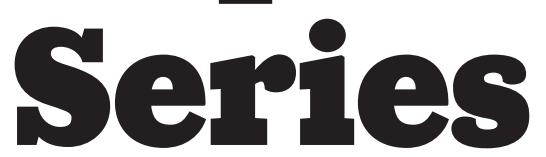


The Mecila Working Paper Series is produced by:

The Maria Sibylla Merian International Centre for Advanced Studies in the Humanities and Social Sciences Conviviality-Inequality in Latin America (Mecila), Rua Morgado de Mateus, 615, São Paulo - SP, CEP 04015-902, Brazil.

Executive Editors: Sérgio Costa, Lateinamerika-Institut, Freie Universität Berlin, Germany Paul Talcott, Lateinamerika-Institut, Freie Universität Berlin, Germany Nicolas Wasser, Mecila, São Paulo, Brazil

Editing/Production: Sérgio Costa, Marcos Nobre, Maya Manzi, Luciane Scarato, Fernando Baldraia dos Santos, Nicolas Wasser, Paul Talcott

This working paper series is produced as part of the activities of the Maria Sibylla Merian International Centre for Advanced Studies in the Humanities and Social Sciences Conviviality-Inequality in Latin America (Mecila) funded by the German Federal Ministry of Education and Research (BMBF).

All working papers are available free of charge on the Centre website: http://mecila.net

Printing of library and archival copies courtesy of the Ibero-Amerikanisches Institut, Stiftung Preußischer Kulturbesitz, Berlin, Germany.

Citation:

Wade, Peter (2018): "Mestizaje and Conviviality in Brazil, Colombia and Mexico", Mecila Working Paper Series, No. 7, São Paulo: The Maria Sibylla Merian International Centre for Advanced Studies in the Humanities and Social Sciences Conviviality-Inequality in Latin America.

Copyright for this edition:

(c) Peter Wade

This work is provided under a Creative Commons 4.0 Attribution-NonCommercial-NoDerivatives 4.0 International License (CC BY-NC-ND 4.0). The text of the license can be read at https:// creativecommons.org/licenses/by-nc-nd/4.0/legalcode.

The Maria Sibylla Merian International Centre for Advanced Studies in the Humanities and Social Sciences Conviviality-Inequality in Latin America cannot be held responsible for errors or any consequences arising from the use of information contained in this Working Paper; the views and opinions expressed are solely those of the author or authors and do not necessarily reflect those of the Maria Sibylla Merian International Centre for Advanced Studies in the Humanities and Social Sciences Conviviality-Inequality in Latin America, its research projects or sponsors.

Inclusion of a paper in the Mecila Working Paper Series does not constitute publication and should not limit publication (with permission of the copyright holder or holders) in any other venue.

Cover photo: (C) Nicolas Wasser 


\title{
Mestizaje and Conviviality in Brazil, Colombia and Mexico
}

Peter Wade

\begin{abstract}
This paper explores the history and meanings of mestizaje in Latin America, with a focus on Brazil, Colombia and Mexico, and assessing its relationship to practices of conviviality. A brief overview of the colonial origins and significance of mixture is followed by an exploration of the way mestizaje figured as a nation-building discourse in the nineteenth and early twentieth centuries. Challenges to the image of the mestizo nation that were strengthened by the regional turn to multiculturalism are then assessed, before re-evaluating mestizaje as a resilient ideology that has not been easily toppled, partly because it contains within it contradictory tensions between conviviality and racism, which make it adaptable. Finally, the paper reviews recent work in genomic science that reiterates the image of the mestizo nation.
\end{abstract}

Keywords: mestizaje | conviviality | racism | nation | multiculturalism

\section{Biographical notes}

Peter Wade is Professor of Social Anthropology at the University of Manchester. $\mathrm{He}$ recently held a British Academy Wolfson Research Professorship (2013-2016). His publications include Blackness and Race Mixture (1993), Race and Ethnicity in Latin America (2010), Race, Nature and Culture: An Anthropological Perspective (2002), Race and Sex in Latin America (2009), Mestizo Genomics: Race Mixture, Nation, and Science in Latin America (Duke University Press, 2014), and Race: An Introduction (Cambridge University Press, 2015). His most recent book is Degrees of Mixture, Degrees of Freedom: Genomics, Multiculturalism and Race in Latin America (Duke University Press, 2017). With Mónica Moreno Figueroa, he is currently co-directing a project on "Latin American Antiracism in a 'Post-Racial' Age". 


\section{Contents}

1. Introduction 1

2. Colonial Hierarchy and Conviviality 2

3. Mestizaje and Conviviality in the New Republics 3

4. Mestizaje, Multiculturalism and Conviviality 6

5. The Resilience of Mestizaje $\quad 7$

6. Mestizaje and Genomics 10

7. Conclusion 12

8. Bibliography 13 


\section{Introduction}

Mestizaje is, in one view, a discourse and practice of conviviality. A Spanish word meaning mixture ${ }^{1}$, it is about mixture across differences understood as "racial". As such, and due to the colonial history of ideas of racial difference, it also necessarily operates across differences of class. And, although it is certainly seen as a process of cultural synthesis, because it is also conceived as involving the sexual reproduction of new generations of mestizos (mixed people), it necessarily works across differences of gender. In this sense, mixture is about crossing social boundaries and making porous the hierarchies of social life, and thus about conviviality, as I will use the concept. However, from another point of view, mestizaje is about reinforcing precisely boundaries and hierarchies or race, class and gender, and is in fact a key mechanism for their reproduction. This essay will explore these contradictory perspectives in the development of racial formations in Brazil, Colombia and Mexico, and in current debates about the dynamics of these self-declared multicultural societies today.

I understand conviviality to mean not simply "living together" or coexistence, but as implying ways of living (discursive and non-discursive practices) based on norms of tolerance, reciprocity, non-hierarchy and solidarity (Adloff 2018). To this extent, I depart somewhat from a more "analytic" definition of conviviality to mean "coexistence as an open field of discursive and non-discursive negotiation" (Maria Sibylla Merian Centre Latin America 2017: 7). I think this apparently neutral definition smuggles in a normative element with the idea of negotiation (especially in an "open" field), insofar as hierarchy is ultimately about the absence of negotiation and the unilateral imposition of power, even if in practice it has to work in more negotiated ways. In that sense, conviviality and hierarchy operate as processes in tension with each other, which structure the social field, between facilitating and curtailing open negotiation. I believe this follows the approach of Gilroy who defines conviviality in terms of "the processes of cohabitation and interaction that have made multiculture an ordinary feature of social life in Britain's urban areas and in postcolonial cities elsewhere" (Gilroy 2004: xi). Although the terms "cohabitation" and "interaction" could be understood as neutral terms designating human social interaction of any kind, I think it is clear that Gilroy is attaching a normative implication to them, especially in using conviviality to "take off from the point where 'multiculturalism' broke down" and to gain "a measure of distance" from the term "identity", which tends to become closed, fixed and reified.

1 The Portuguese word is mestiçagem. 


\section{Colonial Hierarchy and Conviviality}

The first texts touching on mestizaje, in the broadest sense, were colonial documents. ${ }^{2}$ These discussed people called mestizos, often considered to be a problem, because they did not fit into the ideal colonial order that, in its simplest form, distinguished indios (indigenous people), whites/Spanish people and enslaved people. The very term mestizo was seen as disrespectful, almost synonymous with illegitimacy and lack of honor, as mestizos were commonly seen as the result of sex - often non-consensual - between white men and indigenous or enslaved black women (Johnson and LipsettRivera 1998; Wade 2009).

There is a large historiographical literature that analyses how colonial authorities dealt with the processes of mixture that generated many intermediate categories of mestizos and what the status of these people was in the colonial order. Some of this literature focuses on the relative roles played by parentage, physical appearance (e.g. skin color), occupation, education, etc. in defining status and in shaping interactions across differences of colonial hierarchy (Chance 1978; Cope 1994; Gotkowitz 2011; Gutiérrez 1991; Katzew and Deans-Smith 2009; McCaa 1984; Mörner 1967; Seed 1982). In debates about how important "race" was in all this, it is clear that physical appearance was not a simple indicator. The word race (raza) was rarely used, even though what we would now call racialized terms, such as mestizo and mulato, were common. Parentage was important in reckoning so-called limpieza de sangre (purity of blood), which in pre-Conquest Iberia meant freedom from Jewish and "Moorish" (i.e. Islamic) antecedents, but in the New World also came to mean freedom from African or indigenous ancestry, and which was needed to access certain high-status occupations and marital prospects (Martínez 2008). However, an individual's "racial" classification was flexible and could change from one bureaucratic registration (e.g. birth records) to another (e.g. marriage records, criminal records, a census). It was possible to buy a certificate of whiteness (Twinam 2015). A historiographical focus on the so-called casta paintings - eighteenth-century series of stylized depictions of different kinds of mixed people and their parents, mostly from New Spain (Mexico) (Deans-Smith 2005; Katzew 2004) - gives the impression of a highly ordered system, which was probably in practice highly flexible and rather unorderly, especially early on (Rappaport 2014). Conviviality was restricted by an obsessive concern with hierarchies of status and

2 The word mestizaje does not appear in the dictionaries of the Real Academia Española until the 1925 edition, although it was certainly in use before then (Gamio 1916; Molina Enríquez 2004 [1909]). The word mestizo was used from the early colonial period: The writer Inca Garcilaso de la Vega declares himself mestizo in his Comentarios Reales de los Incas, published in Lisbon in 1609 and the word appears in the so-called Diccionario de autoridades (1726-1739); see http://www.rae.es/recursos/ diccionarios. . 
honor - defined to a significant extent by parentage and "blood" - but facilitated by the difficulty of rigorously policing these hierarchies.

\section{Mestizaje and Conviviality in the New Republics}

The next set of texts relating to mestizaje are those written by nation-building elites from the mid-nineteenth through to the mid-twentieth centuries. They were concerned to develop a sense of nationhood - alongside a growing sense of regional Latin American identity, distinct from the United States or Europe (Martí 1891) - in the context of a global order dominated by European ideas of liberalism and modernity, themselves shaped integrally by theories of race. These theories had, since about 1800 , been developed through a comparative scientific anatomy of the human body, which established a biological hierarchy of "races", dominated by whites, in which mixture between "races" was degenerative (Stocking 1982; Wade 2015). This clearly placed Latin American nations in a difficult position and historians have analysed in depth how elites coped (Appelbaum 2016; Appelbaum, Macpherson, and Rosemblatt 2003; Gotkowitz 2011; Graham 1990; Leal and Langebaek 2010; Pérez Vejo and Yankelevich 2017; Stepan 1991).

One way around this was that some Latin American nation-builders reworked ideas of modern liberalism to associate mestizaje, not with degeneration, but with democracy and equality, key elements in the concept of conviviality (Miller 2004). Colombian writer and politician José María Samper wrote of the "marvelous work of the mixture of races" and considered that it "should produce a wholly democratic society, a race of republicans, representatives simultaneously of Europe, Africa and Colombia, and which gives the New World its particular character" (Samper 1861: 299). In a speech to a 1920 conference on Los problemas de la raza en Colombia (The problems of [the] race in Colombia) (Jiménez López et al. 1920), the medic Jorge Bejarano posed the rhetorical question: "What is the result of this variety of races?". His answer was that, politically, it was "the advent of a democracy, because it is proven that the promiscuity of races, in which the element socially considered inferior predominates, results in the reign of democracies". Another contributor to the conference, Luis López de Mesa (Education Minister, 1934-35) said in a later publication that Colombians were "Africa, America, Asia and Europe all at once, without grave spiritual perturbation" and that the country was no longer "the old democracy of equal citizenship only for a conquistador minority, but a complete one, without distinctions of class or lineage" (López de Mesa 1970 [1934]: 14, 7). ${ }^{3}$ These optimistic visions spoke to the ways of living, based on values of tolerance, reciprocity, non-hierarchy and solidarity, which enhance conviviality in an unequal society (Adloff 2018).

3 See also Muñoz Rojas (2011), Villegas Vélez (2005), Restrepo (2007). 
If Colombian elites often portrayed their nation as one in which mixture could work to undo inequalities of race and class, in Mexico this was established as an official state definition of the country, especially after the 1910 Mexican Revolution (Basave Benítez 1992; López-Beltrán and García Deister 2013; Moreno Figueroa and Saldívar 2015; Sue 2013). Chief ideologue José Vasconcelos had an encompassing vision of the Latin American mestizo as an exemplar of the "cosmic race", emblem of "the equality of all men by natural right [and] the social and civic equality of whites, blacks and indios [indigenous people]", and bearer of the "transcendental mission" entrusted to Latin America of "uniting [all] people ethnically and spiritually" (Vasconcelos 1925: 16). In his nationalist tract, Forjando patria (forging fatherland), Manuel Gamio, historian and director of Mexico's International School of American Archaeology and Ethnology, wrote of the early colonial "mix of blood, ideas, industries, virtues and vices" out of which the mestizo appeared with "pristine purity", constituting "the first harmonious product" in which could be detected the originating "racial characteristics" (Gamio 1916: 117). ${ }^{4}$ In 1933 on the basis that "the great Mexican family comes from the crossing of distinct races", the Foreign Ministry denied that the government had "any racial or class prejudice" (FitzGerald and Cook-Martín 2014: 236).

In Brazil the ideas of racial fraternity and democracy were developed during the middle twentieth century - and especially under the populist dictator Getúlio Vargas and the later military dictatorship - into an official representation of the nation, conceived as the polar opposite of the racially segregated and decidedly unconvivial United States (Guimarães 2007; Seigel 2009; Skidmore 1974). This drew on the positive reevaluation of mixture and of African and indigenous heritages developed in the 1930s by Gilberto Freyre, who stated that "miscegenation and the interpenetration of cultures - chiefly European, Amerindian and African culture - together with the possibilities and opportunities for rising in the social scale" traditionally open to non-whites "have tended to mollify the interclass and interracial antagonisms developed under an aristocratic economy", with the result that "perhaps nowhere is the meeting, intercommunication, and harmonious fusion of diverse or, even, antagonistic cultural traditions occurring in so liberal a way as it is in Brazil" (Freyre 1986: xiv, 78). ${ }^{5}$

These ideological nation-building discourses about mestizaje as democratic and racially tolerant drew on interpretations of Latin American histories of mixture as a social practice, but these were always in tension with the persistent racism and racial hierarchy that were also evident in this practice. The historical literature cited above shows that these nation-building ideologues, while lauding mestizaje, often made very clear their contempt for, or at best reservations about, actual black and indigenous

4 See also Brading (1988).

5 See also Burke and Pallares-Burke (2008), Bethencourt and Pearce (2012). 
people, whom they saw as uncivilized and backward. Frequently they saw no reason to hide a preference for European immigrants, whom they thought would improve their nations, by "whitening" them in terms of both "blood" and culture. In Brazil whitening was particularly powerful because, between the 1870s and the 1930s, it managed to attract over 4 million European immigrants, creating a society in which about half the population identified as "white" in the census and whiteness became a dominant value, despite the official representation of the nation as mixed (Hofbauer 2006; Simpson 1993). Mexico and Colombia failed to generate a similar influx of Europeans - which does not mean that whiteness is not also highly valued there (Moreno Figueroa 2010; Sue 2013; Wade 1993).

One consequence of the way the value of mixedness was strongly inflected by the magnetic attraction of whiteness was that other mestizajes, such as those between black and indigenous peoples, has been rendered historically less visible. In colonial and republican times, this mixture - producing mestizos sometimes labelled zambos was looked down upon as creating especially recalcitrant individuals and inferior racial "types" and it was also seen to be disadvantageous for indigenous groups. If these groups were typically seen to need protection, including from whites and mestizos who would usurp their land, undermine their cultures, dilute their indigenous "blood" and, if not impeded, eventually destroy them, then black people were seen as an even greater threat in this respect. Mixture with whites and mestizos might destroy indigenous cultures, but at least the groups concerned would end up as mestizos themselves. Mixture with black people would bring destruction without the compensation of integration into the mestizo mainstream. Despite these attitudes - and, in colonial times, policies to prevent such mixtures - Afro-indigenous mixture was widespread, particularly in north-east Brazil, northern Colombia and the so-called Costa Chica region of Mexico. ${ }^{6}$

The historical literature also pointed out that mestizaje has built into its very foundations a deeply sexist bias, in which higher-status and lighter-skinned men were seen as free to indulge in sexual liaisons with black, indigenous and darker-skinned lowerclass mestizo women, perceived to be sexually (as well as economically) available and without honor or respectability, while women of their own class were not free to do the same (Caulfield 2000; Goldstein 2003; Martinez-Alier [Stolcke] 1989 [1974]; Smith 1997; Wade 2009, 2013a).

Mestizaje was thus revealed as a highly ambivalent discourse and set of practices, as it promoted and facilitated interactions across hierarchical differences of race, class

6 The Costa Chica is the Pacific coastal regions of the southern states of Oaxaca and Guerrero. For a discussion of these and other examples of Afro-indigenous mixture, plus an overview of the field, see Wade (2018). 
and gender, but simultaneously reinforced those hierarchies by attaching greater value to some interactions - those that seemed to move towards whiteness, coded as masculine - and less value to others - those that were perceived to move in the direction of blackness or indigeneity, coded as feminine. Interaction in a hierarchical society could rarely be value neutral - as implied by a view of mestizaje either as an abstract process grasped only a posteriori in terms of the simple existence of mestizos and mestizo cultures, or as unproblematic mixture between consenting adults somehow free from the constraints of the real world. Instead mestizaje was deeply inflected by power-laden perceptions and motives located in inescapable hierarchies.

\section{Mestizaje, Multiculturalism and Conviviality}

A major shift in the discourses and debates surrounding mestizaje occurred in the 1990s with a region-wide shift towards official multiculturalism. This was pre-figured by the rapid growth from the 1960s of indigenous and later black social movements, which sought to defend cultural and land rights and foster strong ethnic identities and political solidarities around indigeneity and blackness/Africanness. These movements built on long-standing traditions of indigenous and black resistance and protest, going back to colonial practices of rebellion, escape, petitioning the authorities, defending some degree of community autonomy, etc. In the twentieth century, black organizations in Brazil sought integration, equal rights and freedom from racial discrimination, while indigenous peoples often fought to defend their lands. But from the 1960s, these efforts took on a new impetus, nurtured by international post-war events, such as decolonization, global anti-racism, challenges to Western political and epistemological authority, improved global communications and rising levels of education in Latin America (Wade 2010: 112-116). All across Latin America, starting in 1988 with the Brazilian constitutional reform, governments began to introduce legislative changes giving new, or greater, rights to indigenous groups and, in some cases, new rights to black or "Afro-descendant" communities. ${ }^{7}$ With regard to Afro-descendants, Brazil and Colombia have led the way, while Mexico has had a much lower profile (Hoffmann and Rodríguez 2007; Paschel 2016; Van Cott 2000; Wade 2010, 2013b).

These currents of ethnic mobilization - and associated academic literature - have generally seen mestizaje primarily and sometimes exclusively through the lens of its inherent racism: it is seen as nothing more than an ideology of whitening, genocidally erasing black and indigenous identities behind a smokescreen of inclusive rhetoric (Gould 1998; Rahier 2014; Stutzman 1981). At the least, mestizaje is seen as a process and ideology that undermines black political solidarity and even identity by

7 The term afrodescendente is often credited to the black Brazilian feminist Sueli Carneiro. It began to be used in Brazil from the late 1990s and gained currency with the Durban 2001 United Nations World Conference Against Racism. 
offering to individuals the possibility of negating "black" identity in favor of being "brown", i.e. mixed (Hanchard 1994; Toplin 1981; Winant 1994). When applied to indigenous people the same basic argument works, but the emphasis tends to be less on personal choice and more on forcible assimilation into the mestizo mainstream when, for instance, indigenous people move to urban environments, breaking a key link between territory and identity (Del Popolo et al. 2007; Radcliffe 1990; Warren 2001), and imposing a process of what Bonfil Batalla (1996) has, writing about Mexico, called "de-Indianization". In both cases, the idea is that the overarching discourse of mestizaje casts blackness and indigeneity in a very negative light, making it hard for people to identify positively with these social locations.

Eschewing the - in this view, entirely false - promise of conviviality contained in mestizaje, these social movements aspire to new forms of conviviality, based on respect for difference, rather than the perceived erasure of difference by a homogeneous mestizo-ness. A key bone of contention in public debates about this multiculturalism (in Latin America and more generally) is the extent to which consolidating the differences which are to be respected - e.g. by promoting ethnic autonomy, language use, territorial rights, preferential access to higher education, etc. - will actually reduce the possibilities of conviviality by erecting and/or reinforcing boundaries and increasing their racialized content, even if they are less hierarchical than before (Bocarejo and Restrepo 2011; Lehmann 2016). This is at the heart of debates in Brazil about the rights and wrongs of race-based affirmative action in relation to university admissions and federal employment (Fry et al. 2007; Guimarães 1999; Htun 2004; Lehmann 2018). As with mestizaje, there is also a sense that multiculturalism can become was from the start? - a top-down project that is easily co-opted by the state to suit its own interests in governance and neo-liberal development. Some have argued that governments may benefit from the creation, in areas often peripheral to state control networks, of collective subjects, which are then bound to the state by multiculturalist policies that may constrain as much as liberate their actions (Gros 1997; Hale 2002; Speed 2005; Wade 2002). Racialized hierarchies of power once again re-emerge in a process aiming to foment conviviality by increasing equality.

\section{The Resilience of Mestizaje}

Alongside the multicultural turn and its associated processes of ethnic mobilization, questions remain about the extent to which these events have effectively toppled discourses and practices of mestizaje. This is partly a question of appreciating the degree of corporatist co-optation of black and indigenous activism and politics (Agudelo 2005; French 2009; Jaramillo Salazar 2014; Paschel 2016; Rahier 2012), which blunts their disruptive and transformative edge. And it is partly a question of re-evaluating mestizaje itself. This requires a deeper insight into the way that the project of mestizaje 
involves not just aiming to produce homogeneity, but also recognizing the racialized diversity that the very idea of the mestizo depends upon: the mestizo is unimaginable without the black, the white, and the indigenous (Wade 2005). Even in contexts where the black and the indigenous are defined as somehow non-national - as blackness is in Ecuador, according to Rahier (2014), or as blackness and indigeneity are often said to be in Argentina, where mass European immigration has dominated definitions of the nation - they are necessarily there as an absent presence, the outside/boundary that relationally constitutes the inside/center. This is shown by Rahier's own extensive work on Ecuador and by recent re-assessments of Argentina's history that reveal the presence of non-whiteness in the national imaginary (Aguiló 2018; Alberto and Elena 2016).

There is also a sense in which it is important to grasp that mestizaje works not just by erecting a smokescreen of lies and falsehoods woven together in a mere rhetoric of inclusion. Mestizaje can certainly contain such rhetoric, but as we well know from Gramscian approaches to power, hegemonic discourses succeed to the extent that they play on elements of social reality that resonate with people's life experiences and perceptions (even if these are partly shaped by the very same hegemonic ideologies). As Stuart Hall (Grossberg 1996; Hall 1996a, 1996b) taught us, hegemonic ideas work by articulating (in the dual sense of linking together and expressing) diverse symbols, ideas, concepts, terms, images and feelings into narratives that are convincing. They are not entirely real - what could be? - but they are not entirely false either.

Positive narratives about the convivial aspects of mestizaje resonate with aspects of many people's lived experience, even as they may also experience its hierarchical and racist aspects (Wade 2005); of course, the social positioning of a person will shape which aspects resonate most strongly. Describing a by low-income neighborhood of Salvador, Brazil, Sansone (2003: 52-53) says that "color is seen as important in the orientation of social and power relations in some areas and moments, while considered irrelevant in others". The local residents perceive a "soft" area of social relations (street corners, parties, the neighborhood, sports, and religion) and a "hard" one (interactions with the police, the world of work, and of marriage and dating). Telles (2004) likewise characterizes Brazil in general in terms of the co-existence of - and tension between - what he calls horizontal and vertical social relations. The realms of friendship, the family, and the neighborhood were marked by the strong presence of horizontal or convivial relations of interaction, mixture, and fairly equal exchange. In contrast, vertical relations of hierarchy and inequality were more obvious in the domains of work, education, health, housing, and politics.

Recent studies tend to modify the idea that the family is a domain of simple conviviality. Sansone identified the world of marriage and dating as a "hard" one and it is well 
known that social distinctions and hierarchies - including ones of race - play a vital role in choosing a mate, whether for marriage or for a more temporary liaison. In Rio de Janeiro, dark-skinned working-class women may attempt, playing on the image of the sexy mulata, to seduce a coroa (literally a crown; figuratively a knight in shining armor), who is an older, whiter, richer man, who will give them money and perhaps put them up in an apartment in return for a sexual relationship (Goldstein 2003). In Cuba, romantic relationships between black and white people are evaluated according to racist stereotypes about blackness (Fernandez 2010); this builds on nineteenthcentury mores according to which color was a key elements in judging the fitness of a spouse for a young person of elite status (Martinez-Alier [Stolcke] 1989 [1974]). In Bogotá, Colombia, black-white couples find themselves subject to racialised and racist ideas about black male and female hypersexuality (Viveros Vigoya 2002, 2008).

It follows, then, that, once formed, families are not easily going to be free from the concerns that shape the conjugal relationships on which they are based. Indeed, Moreno Figueroa $(2008$, 2012) for Mexico and Hordge-Freeman (2015) for Brazil - and, in less detail, Wade (1993) for Colombia - show that families can be prime locations for the operation of racial hierarchy, as the process of producing children becomes a site for preoccupation about racialized appearance, and lighter and darker siblings are marked out and receive different treatment. Studies of assisted reproduction also describe the preoccupation of families with the color and racialized appearance of egg donors (Roberts 2012). These findings are no surprise when one considers more widely the intersection of race and gender (or rather sex) (Collins 2000; Nagel 2003; Wade 2009). As racialized ideas about belonging are mediated in part by physical inheritance, they are also necessarily mediated by ideas about sex and thus also usually about gender. If race and sex/gender are very commonly imbricated, this is even more so in the case of mestizaje, which, while it is a partly discourse about cultural interactions, is also explicitly a discourse about sex between people perceived as racially different, and the children that result.

If even the family can be a site for the articulation of racial hierarchy alongside conviviality, then, rather than dividing social life into distinct domains ruled by either horizontal/soft or vertical/hard relations, we should think about the tension between racial conviviality and racial hierarchy as a constitutive dynamic operating across all social domains, in variable ways. Family may be thought of as a domain in which conviviality has the upper hand, while highly commercialized forms of sex tourism could be a domain in which racial hierarchy and racism are articulated powerfully, only being very marginally inflected by the conviviality of the longer-term relationships between tourists and sex workers, which occur in less commercialized forms of the trade and which occasionally result in marriages of a typically precarious nature (Brennan 
2004; O'Connell Davidson and Sanchez Taylor 1999). Systematic killings of black and indigenous people - whether carried out by police in Rio or by paramilitary forces in indigenous areas of Brazil and the Pacific coastal region of Colombia - can be thought of as a domain in which conviviality is totally eclipsed by racism (Almario 2004; Oslender 2016; Pacheco de Oliveira 2016; Vargas 2018). This racism is allied to class dynamics insofar as the violence is often about control of land, other primary resources (minerals, forest products), and markets; and it is allied to sexism insofar as the violence is often masculinist in tone, whether it targets men or women. The racism implicated in these currents of violence is obfuscated by mestizaje in the sense that this assemblage of discursive and performative elements affords the possibility of elaborating narratives that cast the violence as being "anti-subversive" or as simply "cleansing" society of "anti-social" presences that are causing crime or blocking "progress". But this should not blind us to the real presence of processes of conviviality that co-exist with this murderous and racist violence. It is this co-existence of racism and conviviality that lies at the heart of mestizaje.

\section{Mestizaje and Genomics}

A recent twist on the question of the challenge to and resilience of mestizaje has been given form a perhaps unexpected quarter - genomic science. It is not so unexpected once we recall that scientific interest in race - and in race mixture - has a long history. Science has, of course, fought hard against the racist science of the nineteenth and early twentieth centuries and has been a key tool in the gradual global shift towards anti-racism that began in about 1920s. But in challenging the biological status of the race concept, life science has not relinquished an interest in human biological diversity, including the continent-shaped dimensions of it that used to be called "racial" (Reardon 2005). In Latin America, a concern with measuring degrees of mixture goes back to the 1940s, soon after the first scientific techniques merged to measure degrees of "racial mixture" (Ottensooser 1944) and has been has been continuous ever since (Wade et al. 2014). Then, as now, the method uses populations sampled in West Africa, Europe, and among Amerindian communities as reference or baseline points to calculate the proportions of African, European and native American genetic ancestry in Latin American mestizo populations. For our purposes here, two things stand out from this science (for details, see Wade 2017; Wade et al. 2014).

First, the concern with measuring degrees of mixture seems almost obsessive. There is a medical genetic rationale at work here, to do with being able to control for ancestry when comparing "cases" (people with a given medical disorder) with "controls" (healthy people). If you want to track down genetic variants you think might be causally linked to the disorder, because they occur more frequently among people with the disorder, you want to be sure you are not chasing variants that are not in fact linked to the 
disorder but are simply more frequent among people with the disorder because they happen, by accident of sampling, to have more, say, European ancestry than the controls. Matching cases and controls for ancestry reduces this confounding effect. Latin American geneticists are keen to show that samples labelled "Hispanic," "Latino," or "Latin American" - common enough labels in US and other labs - are in fact highly diverse in terms of their genetic ancestry: hence the concern with measuring degrees of mixture of many populations within Latin America. However, it is clear that the attention given to mixture goes beyond this rationale, especially when the scientists disseminate their results for a general audience or science writers take up the findings.

There is a tension within these genomic studies between concepts of purity and mixture, which parallels the tension between racism and conviviality that characterizes mestizaje. On the one hand, genomic research in Latin America consistently highlights that everyone is mixed: even people who see themselves and are seen by others as white, black, indigenous, etc. are genetically mixed. Recent advances in genetic technology allows the minute examination of diverse parts of the genome, including for example the mitochondrial DNA (mtDNA), which people inherit from their mothers in unchanged form (i.e. the DNA sequence is not recombined or "shuffled" in the process of sexual reproduction, in contrast to the main body of autosomal DNA, which shuffles together DNA from both parents). Examination of the mtDNA of mestizos and "whites" reveals the presence of Amerindian and/or African markers originating in some longforgotten female ancestor. Mixture is pervasive.

On the other hand, genomic studies routinely identify certain populations as "black" or "Afrodescendant" and "Amerindian", which are classified as different from "mestizos" (or "whites"); these populations are relatively less mixed. In Brazil, Colombia and Mexico, this is especially the case for indigenous communities, which are the source of the samples used as a reference baseline for Amerindian ancestry and which must therefore represent 100 percent Amerindian ancestry, at least in theory. ${ }^{8}$ In Colombia, this differentiation is also common for black populations; it is less common in Brazil, where a major strand of genomic research has insisted on the highly mixed genetic ancestry of "black" populations; and it is less common in Mexico, where there has been little focus on the genetics of Afro-Mexican populations, compared to the overwhelming focus on mestizo and indigenous people.

In short, genomics both reinforces multiculturalist visions of the nation, in which indigenous and black minorities are identified as different and highlighted, and yet

8 The reference samples are not the same as the communities from which they come. Usually only certain indigenous individuals are chosen for the reference sample - e.g. those whose grandparents or even great-grandparents were born in the community or locality, or whose grandparents or great-grandparents spoke an indigenous language. That is, the geneticists try to choose relatively unmixed individuals. 
also insists on the mestizo character of the nation, which goes against the grain of multiculturalism and re-inscribes older visions of mixedness as the essence of the people, often making an explicit or implicit contrast with nations seen as less mixed, such as the United States or many (especially northern) European nations. My view is that the overall message conveyed by genomic studies is one of mixedness.

The second theme that stands out - and which supports this view - is the way DNA data have been used in public debates in Brazil about affirmative action in university admissions (Kent, Santos, and Wade 2014; Kent and Wade 2015). Genomic studies that "proved" that people identifying as "black" were in reality mixed were adduced to attack government policies that targeted self-identified "black" people and allowed them access to race-based quotas for university entrance. One prominent geneticist suggested that social policy should be guided by the fact that biologically speaking races did not exist and that awareness of this fact "meets the utopian wish of a non-racialist, 'colour blind' society, where the singularity of the individual is valued and celebrated" (Pena and Birchal 2006: 20). That is, genetic data were used in support of the idea of convivial society, which was also a mixed one. The same geneticist speculated that "if the many white Brazilians who have Amerindian or African mitochondrial DNA were to become aware of this, they would value more highly the exuberant genetic diversity of our people and, perhaps, would construct in the twenty-first century a more just and harmonious society" (Pena et al. 2000: 25). In this view, mixedness foments conviviality, while race-based policies and consciousness are seen to create divisiveness and discord.

\section{Conclusion}

Mestizaje has often been seen as top-down process that erases ethnic difference. It has also recently been refigured as a bottom-up process that challenges this homogenization and celebrates the diversity that mixture brings, making the mestizo a disruptive, border-crossing and hybrid figure (Anzaldúa 1987; Klor de Alva 1995; Mallon 1996). Critics have since questioned this view of hybridity as necessarily disruptive, as the idea of hybridity can carry within it the origins and purities that constitute it and, more importantly, the hierarchies that order those origins (Hale 1999; Wade 2004; Young 1995). I advocate a view of mestizaje that sees it as inherently contradictory, involving discourses and practices of conviviality co-existing with discourses and practices of racial hierarchy and racism. The conviviality acts to obfuscate the racism and distract attention from it, but it also exists in its own right, as more than just a smokescreen. This gives added power to its obfuscations and distractions, but it also creates a sui generis racial formation which may provide affordances and footholds for anti-racist actions. For example, for all that mestizaje from above has tried to divide and rule between black and indigenous people, it has also created the possibility of 
alliances between these categories - however much multiculturalist policy is currently reinforcing black-indigenous distinctions (Wade 2018). Or again, mestizaje has helped to create a society in which the inequalities of race and the inequalities of class are often lived together in an integrated way that may help to address the old dilemma about the politics of recognition versus the politics of redistribution. In short, mestizaje can perhaps be read against the grain to exploit its contradictions and tensions in positive ways.

\section{Bibliography}

Adloff, Frank (2018): Practices of Conviviality and the Social and Political Theory of Convivialism, Mecila Working Paper Series, São Paulo: The Maria Sibylla Merian International Centre for Advanced Studies in the Humanities and Social Sciences Conviviality-Inequality in Latin America.

Agudelo, Carlos E. (2005): Retos del multiculturalismo en Colombia: política y poblaciones negras, Medellín: La Carreta Editores, Institut de recherche pour le développment, Universidad Nacional de Colombia, Instituto Colombiano de Antropología e Historia.

Aguiló, Ignacio (2018): The Darkening Nation: Race, Neoliberalism and Crisis in Argentina: University of Wales Press.

Alberto, Paulina and Elena, Eduardo (eds.) (2016): Rethinking Race in Modern Argentina, New York: Cambridge University Press.

Almario, Oscar (2004): "Dinámica y consecuencias del conflicto armado colombiano en el Pacífico: limpieza étnica y desterritorialización de afrocolombianos e indígenas y 'multiculturalismo' de estado e indolencia nacional”, in: Restrepo, Eduardo and Rojas, Axel (eds.): Conflicto e (in)visibilidad: retos en los estudios de la gente negra en Colombia, Popayán: Editorial Universidad del Cauca, 73120.

Anzaldúa, Gloria (1987): Borderlands/La Frontera: The New Mestiza, San Francisco: Aunt Lute Books.

Appelbaum, Nancy P. (2016): Mapping the Country of Regions: The Chorographic Commission of Nineteenth-Century Colombia, Chapel Hill, NC: University of North Carolina Press.

Appelbaum, Nancy P., Macpherson, Anne S., and Rosemblatt, Karin A. (eds.) (2003): Race and Nation in Modern Latin America, Chapel Hill: University of North Carolina Press. 
Basave Benítez, Agustín Francisco (1992): México mestizo: análisis del nacionalismo mexicano en torno a la mestizofilia de Andrés Molina Enríquez, México DF: Fondo de Cultura Económica.

Bethencourt, Francisco, and Pearce, Adrian (eds.) (2012): Racism and Ethnic Relations in the Portuguese-Speaking World, Oxford: Oxford University Press, British Academy.

Bocarejo, Diana and Restrepo, Eduardo (2011): "Introducción: hacia una crítica del multiculturalismo en Colombia", in: Revista Colombiana de Antropología 47, 2 , 7-13.

Bonfil Batalla, Guillermo (1996): México Profundo: Reclaiming a Civilization, translated by Dennis, Philip A., Austin: University of Texas Press.

Brading, David (1988): "Manuel Gamio and Official Indigenismo", in: Bulletin of Latin American Research 7, 1, 75-90.

Brennan, Denise (2004): What's Love Got to Do with It? Transnational Desires and Sex Tourism in the Dominican Republic, Durham: Duke University Press.

Burke, Peter and Pallares-Burke, Maria Lúcia G. (2008): Gilberto Freyre: Social Theory in the Tropics, Oxford: Peter Lang.

Caulfield, Sueann (2000): In Defense of Honor: Sexual Morality, Modernity, and Nation in Early-Twentieth-Century Brazil, Durham, NC: Duke University Press.

Chance, John (1978): Race and Class in Colonial Oaxaca, Stanford: Stanford University Press.

Collins, Patricia Hill (2000): Black Feminist Thought: Knowledge, Consciousness and the Politics of Empowerment, 2nd ed., New York: Routledge.

Cope, R. Douglas (1994): The Limits of Racial Domination: Plebeian Society in Colonial Mexico City, 1660-1720, Madison: University of Wisconsin Press.

Deans-Smith, Susan (2005): "Creating the Colonial Subject: Casta Paintings, Collectors, and Critics in Eighteenth-Century Mexico and Spain", in: Colonial Latin American Review 14, 2, 169-204.

Del Popolo, Fabiana, Oyarce, Ana María, Ribotta, Bruno, et al. (2007): Indigenous Peoples and Urban Settlements: Spatial Distribution, Internal Migration and Living Conditions, Santiago de Chile: CEPAL. 
Fernandez, Nadine T. (2010): Revolutionizing Romance: Interracial Couples in Contemporary Cuba, New Brunswick, NJ: Rutgers University Press.

FitzGerald, David Scott and Cook-Martín, David (2014): Culling the Masses: The Democratic Origins of Racist Immigration Policy in the Americas, Cambridge, MA: Harvard University Press.

French, Jan Hoffman (2009): Legalizing Identities: Becoming Black or Indian in Brazil's Northeast, Chapel Hill: University of North Carolina Press.

Freyre, Gilberto (1986): The Masters and the Slaves: A Study in the Development of Brazilian Civilization, Berkeley, CA: University of California Press.

Fry, Peter, Maggie, Yvonne, Maio, Marcos Chor, et al. (eds.) (2007): Divisões perigosas: políticas raciais no Brasil contemporâneo, Rio de Janeiro: Civilização Brasileira.

Gamio, Manuel (1916): Forjando patria, Mexico City: Librería de Porrúa Hermanos.

Gilroy, Paul (2004): After Empire: Melancholia or Convivial Culture, London: Routledge.

Goldstein, Donna M. (2003): Laughter out of Place: Race, Class, Violence and Sexuality in a Rio Shantytown, Berkeley: University of California Press.

Gotkowitz, Laura (ed.) (2011): Histories of Race and Racism: The Andes and Mesoamerica from Colonial Times to the Present, Durham, NC: Duke University Press.

Gould, Jeffrey L. (1998): To Die in This Way: Nicaraguan Indians and the Myth of Mestizaje, 1880-1965, Durham: Duke University Press.

Graham, Richard (ed.) (1990): The Idea of Race in Latin America, 1870-1940. Austin, TX: University of Austin Press.

Gros, Christian (1997): “Indigenismo y etnicidad: el desafío neoliberal", in: Uribe, María Victoria and Restrepo, Eduardo (eds.): Antropología en la modernidad: identidades, etnicidades y movimientos sociales en Colombia, Bogotá: Instituto Colombiano de Antropología, 15-60.

Grossberg, Lawrence (1996): "On Postmodernism and Articulation: An Interview with Stuart Hall”, in: Morley, David and Chen, Kuan-Hsing (eds.): Stuart Hall: Critical Dialogues in Cultural Studies, London: Routledge, 131-150. 
Guimarães, Antonio Sérgio (1999): Racismo e anti-racismo no Brasil, São Paulo: Editora 34.

(2007): "Racial Democracy”, in: Souza, Jessé and Sinder, Valter (eds.): Imagining Brazil, Lanham MD: Lexington Books, 119-140.

Gutiérrez, Ramón (1991): When Jesus Came, the Corn Mothers Went Away: Marriage, Sexuality and Power in New Mexico, 1500-1846, Stanford: Stanford University Press.

Hale, Charles R. (1999): "Travel Warning: Elite Appropriations of Hybridity, Mestizaje, Antiracism, Equality, and Other Progressive-Sounding Discourses in Highland Guatemala", in: The Journal of American Folklore 112, 445, 297-315.

(2002): "Does Multiculturalism Menace? Governance, Cultural Rights and the Politics of Identity in Guatemala", in: Journal of Latin American Studies 34, 485524.

Hall, Stuart (1996a): "Gramsci's Relevance for the Study of Race and Ethnicity", in: Morley, David and Chen, Kuan-Hsing (eds.): Stuart Hall: Critical Dialogues in Cultural Studies, London: Routledge, 411-440.

(1996b): "The Problem of Ideology: Marxism without Guarantees", in: Morley, David and Chen, Kuan-Hsing (eds.): Stuart Hall: Critical Dialogues in Cultural Studies, London: Routledge, 25-46.

Hanchard, Michael (1994): Orpheus and Power: The Movimento Negro of Rio De Janeiro and São Paulo, Brazil, 1945-1988, Princeton: Princeton University Press.

Hofbauer, Andreas (2006): Uma história do branqueamento ou o negro em questão, São Paulo: Editora UNESP.

Hoffmann, Odile and Rodríguez, María Teresa (eds.) (2007): Los retos de la diferencia. los actores de la multiculturalidad entre México y Colombia. Mexico DF: Centro de Estudios Mexicanos y Centroamericanos - CEMCA; Centro de Investigación y Estudios Superiores en Antropología Social - CIESAS; Institut de Recherche pour le Développement - IRD; Instituto Colombiano de Antropología e Historia; Publicaciones de la Casa Chata.

Hordge-Freeman, Elizabeth (2015): The Color of Love: Racial Features, Stigma, and Socialization in Black Brazilian Families, Austin, TX: University of Texas Press. 
Htun, Mala (2004): "From "Racial Democracy" to Affirmative Action: Changing State Policy on Race in Brazil", in: Latin American Research Review 39, 1, 6089.

Jaramillo Salazar, Pablo (2014): Etnicidad y victimización. genealogías de la violencia y la indigenidad en el norte de Colombia, Bogotá: Ediciones Uniandes.

Jiménez López, Miguel, Mesa, Luis López de, Umaña, Calixto Torres, et al. (1920): Los Problemas de la raza en Colombia, Bogotá: El Espectador.

Johnson, Lyman L. and Lipsett-Rivera, Sonya (eds.) (1998): The Faces of Honor: Sex, Shame, and Violence in Colonial Latin America, Albuquerque: University of New Mexico Press.

Katzew, llona (2004): Casta Painting: Images of Race in Eighteenth-Century Mexico, New Haven: Yale University Press.

Katzew, Ilona and Deans-Smith, Susan (eds.) (2009): Race and Classification: The Case of Mexican America. Stanford: Stanford University Press.

Kent, Michael, Santos, Ricardo Ventura and Wade, Peter (2014): "Negotiating Imagined Genetic Communities: Unity and Diversity in Brazilian Science and Society", in: American Anthropologist 116, 4, 1-13.

Kent, Michael and Wade, Peter (2015): "Genetics against Race: Science, Politics and Affirmative Action in Brazil”, in: Social Studies of Science 45, 6, 816-838.

Klor de Alva, J. Jorge (1995): "The Postcolonization of the (Latin) American Experience: A Reconsideration of "Colonialism," "Postcolonialism" and "Mestizajes"”, in: Prakash, Gyan (ed.): After Colonialism, Imperial Histories and Postcolonial Displacements, Princeton: Princeton University Press, 241-75.

Leal, Claudia and Langebaek, Carl (2010): Historias de raza y nación en América Latina, Bogotá: Universidad de los Andes.

Lehmann, David (2018): The Prism of Race: The Politics and Ideology of Affirmative Action in Brazil, Minnesota: University of Michigan Press.

(ed.) (2016): The Crisis of Multiculturalism in Latin America, Basingstoke: Palgrave Macmillan.

López-Beltrán, Carlos and García Deister, Vivette (2013): "Aproximaciones científicas al mestizo mexicano", in: História, Ciências, Saúde - Manguinhos 20, 2, 391410. 
López de Mesa, Luis (1970 [1934]): De Cómo se ha formado la nación colombiana, Medellín: Editorial Bedout.

Mallon, Florencia E. (1996): "Constructing Mestizaje in Latin America: Authenticity, Marginality and Gender in the Claiming of Ethnic Identities", in: Journal of Latin American Anthropology 2, 1, 170-181.

Maria Sybilla Merian International Centre for Advanced Studies in the Humanities and Social Sciences Conviviality-Inequality in Latin America (Mecila) (2017): Conviviality in Unequal Societies: Perspectives from Latin America. Thematic Scope and Preliminary Research Programme, São Paulo: Maria Sibylla Merian International Centre for Advanced Studies in the Humanities and Social Sciences Conviviality-Inequality in Latin America.

Martí, José (1891): “Nuestra América”, in: La Revista Ilustrada de Nueva York, 10 January.

Martinez-Alier [Stolcke], Verena (1989 [1974]): Marriage, Colour and Class in Nineteenth-Century Cuba: A Study of Racial Attitudes and Sexual Values in a Slave Society, 2nd ed., Ann Arbor: University of Michigan Press.

Martínez, María Elena (2008): Genealogical Fictions: Limpieza De Sangre, Religion, and Gender in Colonial Mexico, Stanford: Stanford University Press.

McCaa, Robert (1984): "Calidad, Clase and Marriage in Colonial Mexico: The Case of Parral, 1788-90", in: Hispanic American Historical Review 64, 3, 477-501.

Miller, Marilyn Grace (2004): Rise and Fall of the Cosmic Race: The Cult of Mestizaje in Latin America, Austin: University of Texas Press.

Molina Enríquez, Andrés (2004 [1909]): Los Grandes problemas nacionales, Alicante: Biblioteca Virtual Miguel de Cervantes.

Moreno Figueroa, Mónica (2008): "Historically-Rooted Transnationalism: Slightedness and the Experience of Racism in Mexican Families", in: Journal of Intercultural Studies 29, 3, 283-297.

(2010): "Distributed Intensities: Whiteness, Mestizaje and the Logics of Mexican Racism", in: Ethnicities 10, 3, 387-401.

(2012): "'Linda Morenita": Skin Colour, Beauty and the Politics of Mestizaje in Mexico", in: Horrocks, Chris (ed.): Cultures of Colour: Visual, Material, Textual, Oxford: Berghahn Books, 167-180. 
Moreno Figueroa, Mónica and Saldívar, Emiko (2015): ““We Are Not Racists, We Are Mexicans": Privilege, Nationalism and Post-Race Ideology in Mexico", in: Critical Sociology 42, 4-5, 515-533.

Mörner, Magnus (1967): Race Mixture in the History of Latin America, Boston: Little Brown.

Muñoz Rojas, Catalina (ed.) (2011): Los Problemas de la raza en Colombia. Más allá del problema racial: el determinismo geográfico y las 'dolencias sociales', Bogotá: Editorial Universidad del Rosario.

Nagel, Joane (2003): Race, Ethnicity, and Sexuality: Intimate Intersections, Forbidden Frontiers, Oxford: Oxford University Press.

O'Connell Davidson, Julia and Sanchez Taylor, Jacqueline (1999): "Fantasy Islands: Exploring the Demand for Sex Tourism", in: Kempadoo, Kamala (ed.): Sun, Sex and Gold: Tourism and Sex Work in the Caribbean, Lanham, MD: Rowman and Littlefield, 37-54.

Oslender, Ulrich (2016): The Geographies of Social Movements: Afro-Colombian Mobilization and the Aquatic Space, Durham, NC: Duke University Press.

Ottensooser, Friedrich (1944): "Cálculo do grau de mistura racial através dos grupos sangüíneos", in: Revista Brasileira de Biologia 4, 531-537.

Pacheco de Oliveira, João (2016): O Nascimento do Brasil e outros ensaios: "pacificação", regime tutelar e formação de alteridades, Rio de Janeiro: Contra Capa.

Paschel, Tianna S. (2016): Becoming Black Political Subjects: Movements and Ethno-Racial Rights in Colombia and Brazil, Princeton: Princeton University Press.

Pena, Sérgio D.J. and Birchal, Telma S. (2006): "A Inexistência biológica versus a existência social de raças humanas: pode a ciência instruir o etos social?", in: Revista USP 68, 10-21.

Pena, Sérgio D.J., Carvalho-Silva, Denise R., Alves-Silva, Juliana, et al. (2000): "Retrato molecular do Brasil", in: Ciência Hoje 159, 16-25.

Pérez Vejo, Tomás and Yankelevich, Pablo (eds.) (2017): Raza y política en Hispanoamérica, México: El Colegio de México, Bonilla y Artigas Editores. 
Radcliffe, Sarah (1990): "Ethnicity, Patriarchy and Incorporation into the Nation: Female Migrants as Domestic Servants in Southern Peru", in: Environment and Planning D: Society and Space 8, 4, 379-393.

Rahier, Jean Muteba (ed.) (2012): Black Social Movements in Latin America: From Monocultural Mestizaje to Multiculturalism, New York: Palgrave Macmillan.

(2014): Blackness in the Andes: Ethnographic Vignettes of Cultural Politics in the Time of Multiculturalism, New York: Palgrave Macmillan.

Rappaport, Joanne (2014): The Disappearing Mestizo: Configuring Difference in the Colonial New Kingdom of Granada, Durham, NC: Duke University Press.

Reardon, Jenny (2005): Race to the Finish: Identity and Governance in an Age of Genomics, Princeton: Princeton University Press.

Restrepo, Eduardo (2007): “Imágenes del 'negro' y nociones de raza en Colombia a principios del siglo XX”, in: Revista de Estudios Sociales 27, 46-61.

Roberts, Elizabeth F. S. (2012): God's Laboratory: Assisted Reproduction in the Andes, Berkeley, CA: University of California Press.

Samper, José María (1861): Ensayo sobre las revoluciones políticas y la condición social de las repúblicas colombianas (hispano-americanas): con un apéndice sobre la orografía y la población de la Confederación Granadina, Paris: Imprenta de E. Thunot y Cia.

Sansone, Livio (2003): Blackness without Ethnicity: Constructing Race in Brazil, Basingstoke: Palgrave Macmillan.

Seed, Patricia (1982): "Social Dimensions of Race: Mexico City, 1753", in: Hispanic American Historical Review 62, 4, 569-606.

Seigel, Micol (2009): Uneven Encounters: Making Race and Nation in Brazil and the United States, Durham, NC: Duke University Press.

Simpson, Amelia (1993): Xuxa: The Mega-Marketing of Gender, Race and Modernity, Philadelphia: Temple University Press.

Skidmore, Thomas (1974): Black into White: Race and Nationality in Brazilian Thought, New York: Oxford University Press.

Smith, Carol A. (1997): "The Symbolics of Blood: Mestizaje in the Americas", in: Identities: Global Studies in Power and Culture 3, 4, 495-521.

Speed, Shannon (2005): "Dangerous Discourses: Human Rights and Multiculturalism in Neoliberal Mexico", in: PoLAR: Political and Legal Anthropology Review 28, $1,29-51$. 
Stepan, Nancy Leys (1991): "The Hour of Eugenics”: Race, Gender and Nation in Latin America, Ithaca, N.Y: Cornell University Press.

Stocking, George (1982): Race, Culture and Evolution: Essays on the History of Anthropology, 2nd ed., Chicago: Chicago University Press.

Stutzman, Ronald (1981): “El Mestizaje: An All-Inclusive Ideology of Exclusion”, in: Whitten, Norman E. (ed.): Cultural Transformations and Ethnicity in Modern Ecuador, Urbana: University of Illinois Press, 45-94.

Sue, Christina A. (2013): Land of the Cosmic Race: Race Mixture, Racism, and Blackness in Mexico, New York: Oxford University Press.

Telles, Edward E. (2004): Race in Another America: The Significance of Skin Color in Brazil, Princeton: Princeton University Press.

Toplin, Robert (1981): Freedom and Prejudice: The Legacy of Slavery in the USA and Brazil, Westport, Connecticut: Greenwood Press.

Twinam, Ann (2015): Purchasing Whiteness: Pardos, Mulattos, and the Quest for Social Mobility in the Spanish Indies, Stanford: Stanford University Press.

Van Cott, Donna Lee (2000): The Friendly Liquidation of the Past: The Politics of Diversity in Latin America, Pittsburgh: University of Pittsburgh Press.

Vargas, João H. Costa (2018): The Denial of Antiblackness: Multiracial Redemption and Black Suffering, Minneapolis: University of Minnesota Press.

Vasconcelos, José (1925): La Raza cósmica: misión de la raza iberoamericana. notas de viajes a la América del Sur, Madrid: Agencia Mundial de Librería.

Villegas Vélez, Alvaro Andrés (2005): "Raza y nación en el pensamiento de Luis López de Mesa: Colombia, 1920-1940", in: Estudios Políticos 26, 209-232.

Viveros Vigoya, Mara (2002): “Dionysian Blacks: Sexuality, Body, and Racial Order in Colombia", in: Latin American Perspectives 29, 2, 60-77.

(2008): "Más que una cuestión de piel. Determinantes sociales y orientaciones subjetivas en los encuentros y desencuentros heterosexuales entre mujeres y hombres negros y no negros en Bogotá", in: Wade, Peter, Urrea Giraldo, Fernando and Viveros Vigoya, Mara (eds.): Raza, etnicidad y sexualidades: ciudadanía y multiculturalismo en América Latina, Bogotá: Instituto CES, Facultad de Ciencias Humanas, Universidad Nacional de Colombia, 247278. 
Wade, Peter (1993): Blackness and Race Mixture: The Dynamics of Racial Identity in Colombia, Baltimore: Johns Hopkins University Press.

(2002): "The Colombian Pacific in Perspective", in: Journal of Latin American Anthropology 7, 2, 2-33.

(2004): "Images of Latin American Mestizaje and the Politics of Comparison", in: Bulletin of Latin American Research 23, 1, 355-366.

(2005): "Rethinking Mestizaje: Ideology and Lived Experience", in: Journal of Latin American Studies 37, 239-257.

(2009): Race and Sex in Latin America, London: Pluto Press.

(2010): Race and Ethnicity in Latin America, 2nd ed., London: Pluto Press.

(2013a): "Articulations of Eroticism and Race: Domestic Service in Latin America", in: Feminist Theory 14, 2, 187-202.

(2013b): "Brazil and Colombia: Comparative Race Relations in South America", in: Bethencourt, Francisco and Pearce, Adrian (eds.): Racism and Ethnic Relations in the Portuguese-Speaking World Oxford: Oxford University Press, British Academy, 35-48.

(2015): Race: An Introduction, Cambridge: Cambridge University Press.

(2017): Degrees of Mixture, Degrees of Freedom: Genomics, Multiculturalism, and Race in Latin America, Durham, NC: Duke University Press.

(2018): "Afro-Indigenous Interactions, Relations, and Comparisons", in: Andrews, George Reid and de la Fuente, Alejandro (eds.): Afro-Latin American Studies: An Introduction, Cambridge: Cambridge University Press, 92-129.

Wade, Peter, López Beltrán, Carlos, Restrepo, Eduardo, et al. (eds.) (2014): Mestizo Genomics: Race Mixture, Nation, and Science in Latin America, Durham NC: Duke University Press.

Warren, Jonathan W. (2001): Racial Revolutions: Antiracism and Indian Resurgence in Brazil, Durham: Duke University Press.

Winant, Howard (1994): Racial Conditions: Politics, Theory, Comparisons, Minneapolis: University of Minnesota Press.

Young, Robert (1995): Colonial Desire: Hybridity in Theory, Culture and Race, London: Routledge. 


\section{Working Papers published since 2017:}

1. Maria Sybilla Merian International Centre for Advanced Studies in the Humanities and Social Sciences Conviviality-Inequality in Latin America (Mecila) (2017): "Conviviality in Unequal Societies: Perspectives from Latin America: Thematic Scope and Preliminary Research Programme".

2. Müller, Gesine (2018): "Conviviality in (Post)Colonial Societies: Caribbean Literature in the Nineteenth Century".

3. Adloff, Frank (2018): "Practices of Conviviality and the Social and Political Theory of Convivialism".

4. Montero, Paula (2018): "Syncretism and Pluralism in the Configuration of Religious Diversity in Brazil".

5. Appadurai, Arjun (2018): "The Risks of Dialogue".

6. Inuca Lechón, José Benjamín (2018): "Llaktapura sumak kawsay / Vida plena entre pueblos. Un concepto emancipatorio de las nacionalidades del Ecuador".

7. Wade, Peter (2018): "Mestizaje and Conviviality in Brazil, Colombia and Mexico". 